\title{
Effect of socioeconomic factors on the yields of family-operated milk production systems
}

\section{Efeito de fatores socioeconômicos sobre a rentabilidade de sistemas de produção de leite com economia familiar}

\author{
Djalma Ferreira Pelegrini ${ }^{1}$; Marcos Aurélio Lopes ${ }^{2 *}$; Fabiana Alves Demeu ${ }^{3}$; \\ Águida Garreth Ferraz Rocha4; Fábio Raphael Pascotti Bruhn"; \\ Pedro Salermo Casas ${ }^{6}$
}

\begin{abstract}
This study analysed the effect of socioeconomic factors on the yields of 28 family-operated dairy farms in the mesoregion of the Triângulo/Alto Paranaiba in Minas Gerais State, Brazil, to identify which components constituted greater proportions of the total costs and operating efficiency and those components' effects on revenue. Data were collected from January to December 2013. The socioeconomic factors, place of residence, producer's age, education level, and land tenure were evaluated for their effects on the variables, gross margin, net margin, yield, and profitability. In this study, none of these socioeconomic factors affected the economic variables. Of the net operating costs, the components that constituted most of the dairy farming costs, in descending order, were feed, labour and sanitation. For total costs, the components in descending order were feed, depreciation and return on invested capital. Of the net operating costs, the components constituting most of the dairy business revenue, in descending order, were feed, miscellaneous expenses and labour.
\end{abstract}

Key words: Milk cattle breeding. Production cost. Management.

\section{Resumo}

Objetivou-se analisar o efeito de fatores socioeconômicos na rentabilidade de 28 propriedades leiteiras em regime de economia familiar localizadas na mesorregião do Triângulo / Alto Paranaíba, estado de Minas Gerais. Especificamente, pretendeu-se, ainda, identificar os componentes que exerceram maiores representatividades sobre os custos total e operacional efetivo, além do impacto de cada um deles na receita. Os dados foram coletados no período de janeiro a dezembro de 2013. Avaliou-se o efeito dos fatores socioeconômicos local de residência, idade e escolaridade dos produtores, bem como posse da terra sobre as variáveis margem bruta, margem líquida, rentabilidade e lucratividade. Neste estudo, nenhum dos fatores socioecônomicos estudados influenciaram nas variáveis econômicas. Os itens componentes do custo operacional efetivo que exerceram maiores representatividades sobre o custo da

\footnotetext{
${ }^{1}$ Pesquisador, Empresa de Pesquisa Agropecuária de Minas Gerais, EPAMIG, Belo Horizonte, MG, Brasil. E-mail: djalma@, epamig.br

2 Prof. Titular, Universidade Federal de Lavras, UFLA, Lavras, MG, Brasil. E-mail: malopes@ufla.br

3 Prof., Instituto Federal de Rondônia, IFRO, Bolsista CAPES Pró Doutoral, Discente, Curso de Doutorado do Programa de PósGraduação em Ciências Veterinárias, UFLA, Ariquemes, RO, Brasil. E-mail: fabiana.alves@ifro.edu.br

4 Prof ${ }^{a}$, Universidade Federal de Uberlândia, UFU, Uberlândia, MG, Brasil. E-mail: aguidagarreth@gmail.com

5 Prof., Centro de Controle de Zoonoses da Universidade Federal de Pelotas, UFPel, Pelotas, RS, Brasil. E-mail: fabio_rpb@, yahoo.com.br

6 Discente, Curso de Graduação em Medicina Veterinária, UFLA, Lavras, MG, Brasil. E-mail: pedrosalermo@gmail.com

* Author for correspondence
} 
atividade leiteira, em ordem decrescente, foram a alimentação, mão de obra e sanidade; enquanto que os do custo total, em ordem decrescente, foram a alimentação, depreciação e remuneração do capital investido. Os itens componentes do custo operacional efetivo com maiores representatividades na receita da atividade leiteira, em ordem decrescente, foram a alimentação, despesas diversas e mão de obra.

Palavras-chave: Bovinocultura de leite. Custo de produção. Gestão.

\section{Introduction}

Family farming is important in Brazilian agricultural production. In total, 4,367,902 properties of this type were identified in 2006, representing $84.4 \%$ of agricultural establishments and occupying 80.25 million hectares, i.e., $24.3 \%$ of the total area occupied by agricultural activities (IBGE, 2006a). Despite its small proportion in terms of area occupied, family farming is responsible for a significant proportion of the food production. The 2006 Agricultural Census revealed that $70 \%$ of beans, $46 \%$ of corn, $38 \%$ of coffee, $34 \%$ of rice, $58 \%$ of milk and $59 \%, 50 \%$ and $30 \%$ of pig, poultry and cattle breeding stock, respectively, originated from Brazilian family farms (IBGE, 2006b).

The last agricultural census found that the average income on a family farm was $R \$ 13,600$, with animal activity taking second place in terms of production value, especially with large animals, which represented $14 \%$ of the trade value. In Minas Gerais, 167,153 family farming units produced 2,518,835,595 litres of cow's milk/year (IBGE, 2006c).

Family farming properties are usually administered by the families themselves, who often keep no records and remain completely unaware of dairy farming production costs. Thus, per Lopes et al. (2004a), they fail to economically evaluate their activity, keep detailed information or use their production factors (land, labour and capital) efficiently and economically. They also fail to locate bottlenecks upon which to concentrate managerial and/or technological efforts to be successful and maximize profits and/or minimize costs (LOPES et al., 2004b).
Several researchers have attempted to estimate the production costs and study the economic viability of milk production (LOPES et al., 2004b; CARVALHO et al., 2009; LOPES et al., 2009; MOURA et al., 2010; LOPES et al., 2011a; TEIXEIRA JÚNIOR et al., 2015, 2016; ASSIS et al., 2017). However, few have analysed yields or demonstrated which components constitute the greatest proportions of milk production costs in family-operated properties (LOPES et al., 2007a; 2008 ; 2010). Given the importance of this segment for Brazil and the state of Minas Gerais (MG), this study analysed the effects of several socioeconomic factors on the yields of family-operated dairy farms in the mesoregion of Triângulo/Alto Paranaiba. Specifically, components were identified that represented the greatest proportions of total costs (TC) and net operating costs (NOC) and each component's proportion of the revenue.

\section{Materials and Methods}

Data were analysed from 28 family-operated milk production systems in the mesoregion of Triângulo/Alto Paranaiba, MG, in 2013. The city of Uberlândia provided nine properties; Prata provided six; Indianapólis and Patos de Minas, provided three each; Monte Alegre de Minas and Tupaciguara provided two each; and finally, the cities of Presidente Olegário, Lagoa Formosa and Canápolis provided one each. These properties were chosen using nonprobability judgemental sampling, considering the following criteria: availability and quality of the husbandry and financial data, the farmer's consent and interest in the research, and the researchers' ease of access to evidence sources 
(LOPES et al., 2015). Producers recorded the data in field books throughout the year, which the researchers collected at each monthly visit.

The following yield indicators were used: gross margin (the revenue value subtracted from the NOC), net margin (the revenue value subtracted from the total operating costs [TOC]) (MATSUNAGA et al., 1976), and results (revenue minus the TC) (BARROS, 1948). The following were also calculated. Profitability 1 was the result divided by the total revenue multiplied by 100 [Profitability $1(\%)=($ result $/$ total revenue $) \times 100$ ], and Yield 1 was the result divided by total assets plus TC, multiplied by 100 [Yield $1(\%)=$ result/ (total assets + net operating cost) $\times 100]($ SEBRAE, 1998). Profitability 2 was the net margin divided by total revenue, multiplied by 100 [Profitability 2 $(\%)=($ net margin/total revenue $) \times 100]$, and Yield 2 was the net margin divided by total assets plus the net operating cost, multiplied by 100 [Yield $2(\%)=$ net margin/(total assets + net operating cost $) \times 100]$ (LOPES et al., 2011a).

When performing a full-stock inventory, each asset's value and useful life was calculated and subsequently grouped into pre-established categories: improvements, machinery, vehicles, equipment, implements, tools, cattle and furniture. The criteria proposed by Lopes et al. (2011a) were adopted when the farmers lacked the necessary information concerning the value and date of acquisition to estimate the updated values and remaining useful life.

To estimate the percentage of the net operating cost (NOC) that each item accounted for relative to the milk sales revenue, the expenditure on the NOC component being evaluated was divided by the milk sales revenue (LOPES et al., 2011a). An annual rate of $6.00 \%$ was used to estimate the return on capital invested, and for land remuneration, the lease value practised in the region was used, estimated at $1 \mathrm{~kg}$ milk/ha/day (LOPES; CARVALHO, 2000).

Descriptive statistics were used to describe the variables, economic indicators, and technical and managerial indices. These statistics were expressed as the mean, standard deviation and minimum and maximum values (BRUHN et al., 2017). The effects of the socioeconomic indicators, place of residence, producer's age and education level, and land tenure, on gross and net margin, result, yield and profitability were evaluated. The Levene test was used to verify equality of variance, and the Shapiro-Wilk test was used to verify normal distributions. Because the data were not normally distributed, they were evaluated using the nonparametric Mann-Whitney test (MAROCO, 2007). A minimum confidence level of $95 \%$ was adopted on all inductive statistical analyses. All statistical analyses were performed using SPSS 20.0 statistical software (IBM, 2011).

\section{Results and Discussion}

All production systems studied were based on pasture production, with supplementation in $81.48 \%$ of the cases. In most cases (25 properties, $89.29 \%$ ), the cows were Dutch/Zebu crosses, which varied in degree between $1 / 2$ and $7 / 8$. At one property, the cows were Gyr breed (3.70\%), and at another, the cows were the Jersey breed (3.70\%). At most properties $(70.37 \%)$, cows were milked twice daily, $66.67 \%$ using a milking machine and $74.07 \%$ with the "calves at foot". Males were discarded at birth in $11.11 \%$ of the surveyed properties. The properties were generally small, with areas of 10.00 to 76.46 $\mathrm{h}$ (Table 1) and low numbers of lactating cows ( 7 to 65). High standard deviation values indicated that the properties were dissimilar from one another.

Most farmers $(88.89 \%)$ resided on the property, and in $74.07 \%$ of cases, their land was inherited. Regarding age, $51.85 \%$ were under 50 years old. In terms of education, $55.56 \%$ had reached only primary school level. These values were lower than those in Costa et al.'s (2013) study, conducted in northwest Santa Catarina, where 3\% of the surveyed farmers were illiterate, $73 \%$ had only primary education, $16 \%$ had secondary education, $8 \%$ had higher education, and all were between 39 and 55 years old. 
Table 1. Descriptive statistics of the resources available on 28 family-operated dairy farms in the Triangulo Mineiro and Alto Paranaiba (MG) region from January-December 2013, in reals (R\$) and as a percentage (\%).

\begin{tabular}{|c|c|c|c|c|}
\hline Specification & Mean $(\mathrm{R} \$ \& \%)$ & $\mathrm{SD}(\%)$ & $\begin{array}{l}\text { Minimum } \\
(\mathrm{R} \$ \& \%)\end{array}$ & $\begin{array}{l}\text { Maximum } \\
(\mathrm{R} \$ \& \%)\end{array}$ \\
\hline Asset value in land & $\begin{array}{c}662,968.79 \\
(76.09)\end{array}$ & $\begin{array}{c}1,720,193.43 \\
(97.73)\end{array}$ & $0.00(0.00)$ & $\begin{array}{c}9,203,700.00 \\
(96.16)\end{array}$ \\
\hline Asset value without land & $\begin{array}{l}208,363.44 \\
(23.91)\end{array}$ & $\begin{array}{c}126,687.28 \\
(7.20)\end{array}$ & $\begin{array}{c}74,235.00 \\
(47.36)\end{array}$ & $\begin{array}{l}583,161.88 \\
\quad(6.09)\end{array}$ \\
\hline Value of improvements & $\begin{array}{c}73,192.82 \\
(35.13)\end{array}$ & $\begin{array}{c}53,315.91 \\
(42.08)\end{array}$ & $0.00(0.00)$ & $\begin{array}{c}234,511.88 \\
(40.21)\end{array}$ \\
\hline Value of equipment & $9,660.32(4.64)$ & $9,722.49(7.67)$ & $1,100.00(1.48)$ & $34,250.39(5.87)$ \\
\hline Value of tools & $192.19(0.09)$ & $139.87(0.11)$ & $0.00(0.00)$ & $510.00(0.09)$ \\
\hline Value of implements & 7,060.93 (3.39) & $9,422.51(7.44)$ & $0.00(0.00)$ & $31,700.00(5.44)$ \\
\hline Value of machinery & $\begin{array}{c}43,686.91 \\
(20.97)\end{array}$ & $\begin{array}{c}37,545.40 \\
(29.64)\end{array}$ & $1,685.00(2.27)$ & $\begin{array}{c}184,725.00 \\
(31.68)\end{array}$ \\
\hline Value of animals & $\begin{array}{l}73,639.17 \\
(35.34)\end{array}$ & $\begin{array}{c}44,935.76 \\
(35.47)\end{array}$ & $\begin{array}{c}18,000.00 \\
(24.25)\end{array}$ & $\begin{array}{l}201,000.00 \\
\quad(34.47)\end{array}$ \\
\hline Value of livestock & $916.67(0.44)$ & $1,261.46(1.00)$ & $0.00(0.00)$ & $4,000.00(0.69)$ \\
\hline Value of furniture & $14.44(0.01)$ & $75.00(0.06)$ & $0.00(0.00)$ & $390.00(0.07)$ \\
\hline Value of vehicles & $0.00(0.00)$ & $0.00(0.00)$ & $0.00(0.00)$ & $0.00(0.00)$ \\
\hline Total fixed assets & $871,332.24$ & $1,760,193.44$ & $156,733.00$ & $9,571,245.00$ \\
\hline Area (ha) & 31.75 & 21.42 & 10.00 & 76.46 \\
\hline Asset value in land/ha $(\mathrm{R} \$ / \mathrm{ha})$ & $12,493.96$ & $5,410.46$ & 0.00 & $22,000.00$ \\
\hline Total fixed assets/ha (R\$/ha) & $8,525.62$ & $6,283.39$ & $1,961.70$ & $27,749.72$ \\
\hline Fixed assets per lactating cow ( $\mathrm{R} \$ / \mathrm{cow})$ & $41,312.06$ & $64,504.85$ & $5,224.43$ & $354,490.56$ \\
\hline Fixed assets per $\mathrm{kg}$ of milk sold $(\mathrm{R} \$ / \mathrm{kg})$ & 14.01 & 20.98 & 1.01 & 111.59 \\
\hline
\end{tabular}

$\mathrm{SD}=$ standard deviation

In this study, the socioeconomic factors (place of residence, producers' age and educational level, and land tenure) had no effect ( $\mathrm{p}>0.05)$ on the variables, gross margin, net margin, Yield 1, Profitability 1, Yield 2 or Profitability 2. Although education produced no significant differences in this study, it does affect work yield (STÜLP, 2006). For Solano et al. (2006), the combination of region, property characteristics, decision-making strategies and producer biographies explained much of the variation in farm management practices and managerial capacities, which had repercussions on economic results. Education level was one of the more influential of these variables in terms of adopted management practices.
Land represented $76.09 \%$ of the total equity and had an average value of $\mathrm{R} \$ 662,968.79$. The minimum value of zero occurred because two properties' lands were rented. The equity value without land averaged R\$208,363.44, representing $23.91 \%$ of the total equity (Table 1 ). These values are similar to those presented by SEBRAE (2006), who reported that $70.67 \%$ of the interviewed milk producers' capital was invested in land, and lower than the $66.14 \%$ reported by Lopes et al. (2010).

Animals represented the greatest proportion of equity without considering land, averaging $\mathrm{R} \$$ $73,639.17$ (35.34\%), followed by improvements $(35.13 \%)$, machinery $(20.97 \%)$ and equipment (4.64\%), which totalled US\$ 200,179.32. This 
suggests low investment in production systems, which may result in production system failures and low yields. The percentage of equity without considering land was near the $33.86 \%$ cited by Lopes et al. (2010) but lower than the $46.15 \%$ cited by Lopes et al. (2007a) and higher than de Moraes et al. (2016) results $(24.30 \%$ of the total investment was in animals, and $21.95 \%$ was in improvements). These studies were all of family-operated properties.
Total revenue corresponds to the sum of the values from milk sales (73.24\%), animals $(20.67 \%)$ and other revenues (6.09\%) (Table 2). The milk sales proportion was near the $73.55 \%$ obtained by Silva and Silva (2013) and the $76.90 \%$ by Lopes et al. (2007a) but below the $92.00 \%$ found by Lopes et al. (2010) when they evaluated family-operated properties. However, it was greater than the $64.68 \%$ found by Lopes et al. (2006).

Table 2. Descriptive statistics of the percentage (\%) of each revenue item for 28 family-operated dairy farms in the Triangulo Mineiro and Alto Paranaiba (MG) region for January-December 2013

\begin{tabular}{lcccc}
\hline \multicolumn{1}{c}{ Item } & Mean & SD & Minimum & Maximum \\
\hline Sale of milk & 73.24 & 20.97 & 0.00 & 98.06 \\
Sale of animals & 20.67 & 14.82 & 0.00 & 63.20 \\
Sale of manure & 0.00 & 0.00 & 0.00 & 0.00 \\
Other income & 6.09 & 19.30 & 0.00 & 100.00 \\
\hline
\end{tabular}

$\mathrm{SD}=$ standard deviation

The average percentage of animal sales $(20.67 \%)$ was also near the $22.02 \%$ found by Lopes et al. (2007a) and higher than the $6.00 \%$ in Lopes et al. (2010) study. This average value could be lower; however, two properties were atypical. One producer had $63.20 \%$ of his revenue attributed to animal sales. In this case, he used milk for cheesemaking and when possible, he acquired animals producing $8-10 \mathrm{~kg} / \mathrm{milk} /$ day in the municipality of João Pinheiro and resold them in Uberlândia for more money. In another case, the proportion was $58.55 \%$, but part of the herd, not reared specifically for milk, was intended for slaughter. In these cases, some cows were milked in the early lactation period but withdrawn from milking and traded because of their decreased production due to low persistence. These factors contributed to the high standard deviations of the animal sales proportions (Table 2).

No properties traded in manure, which explains the nil values in its contribution to total revenue. This was due to technical guidance as $62.96 \%$ of the properties were assisted, two (7.41\%) by Full
Bucket (Balde Cheio) technicians, nine (33.33\%) by EMATER and six (22.22\%) by the Department of Family Agriculture of the Municipality of Uberlândia (Secretaria de Agricultura Familiar da Prefeitura Municipal) programme. The farmers were advised to keep manure pits to exploit manure production or to use it directly on the fields. Wastage occurred, confirming the observations of Lopes et al. (2008a), who found great wastage due to improper storage conditions. Lopes et al. (2008b) stated that using manure lowers meadow maintenance costs, although it initially means a revenue reduction.

The other revenue item relates to cheese sales, agricultural machinery rentals, obsolete equipment sales and silage sales. Table 3 shows that the maximum percentage of $100 \%$ related to a single property with a legalized agribusiness that only marketed cheese during the studied period. Lopes et al. (2006) revealed that cheese production and marketing were more profitable than marketing milk in natura and represents an alternative method of increasing milk producers' incomes. 
Table 3. Descriptive statistics of the summary of yield analysis for the milk production activity of 28 family-operated dairy farms, in the Triangulo Mineiro and Alto Paranaiba (MG) region for January-December 2013.

\begin{tabular}{|c|c|c|c|c|}
\hline Specification & Mean & SD & Minimum & Maximum \\
\hline Income (R\$) & $117,426.55$ & $122,168.72$ & $23,646.31$ & $567,597.33$ \\
\hline Milk (R\$) & $94,290.57$ & $116,746.83$ & 0.00 & $553,597.33$ \\
\hline Animals $(\mathrm{R} \$)$ & $16,796.13$ & $15,737.34$ & 0.00 & $54,500.00$ \\
\hline Manure (sub-products) $(\mathrm{R} \$)$ & 0.00 & 0.00 & 0.00 & 0.00 \\
\hline Other income (cheese) $(\mathrm{R} \$)$ & $6,339.85$ & $21,060.99$ & 0.00 & $108,711.97$ \\
\hline Total operating costs (TOC) (R\$) & $99,954.05$ & $100,923.89$ & $17,196.92$ & $492,819.54$ \\
\hline Effective operating costs (EOC) $(\mathrm{R} \$)$ & $73,793.90$ & $89,664.44$ & $4,076.34$ & $434,137.86$ \\
\hline Cost with depreciation (R\$) & $17,421.49$ & $12,876.61$ & $2,648.22$ & $50,545.68$ \\
\hline Family labour $(\mathrm{R} \$)$ & $8,738.67$ & $2,168.00$ & $8,136.00$ & $16,272.00$ \\
\hline Total cost (TC) (R\$) & $124,413.67$ & $115,419.31$ & $28,286.73$ & $564,030.54$ \\
\hline Fixed costs $(\mathrm{FC})(\mathrm{R} \$)$ & $40,837.83$ & $28,579.02$ & $10,594.27$ & $115,739.76$ \\
\hline Land payments (R\$) & $10,274.51$ & $8,948.40$ & 0.00 & $29,715.28$ \\
\hline Invested capital payments $(\mathrm{R} \$)$ & $13,073.05$ & $8,380.49$ & $4,420.10$ & $34,630.16$ \\
\hline Owner payments $(\mathrm{R} \$)$ & 0.00 & 0.00 & 0.00 & 0.00 \\
\hline Taxes $(\mathrm{R} \$)$ & 68.79 & 187.57 & 0.00 & 848.64 \\
\hline Depreciation $(\mathrm{R} \$)$ & $17,421.49$ & $12,876.61$ & $2,648.22$ & $50,545.68$ \\
\hline Variable costs $(\mathrm{VC})(\mathrm{R} \$)$ & $83,575.84$ & $91,172.15$ & $12,288.43$ & $448,290.78$ \\
\hline Effective operating costs (without tax) (R\$) & $73,725.11$ & $89,553.24$ & $4,076.34$ & 433.289 .22 \\
\hline Working capital payments (R\$) & $1,112.07$ & $1,403.91$ & 76.09 & $6,865.56$ \\
\hline Gross margin $1 *(\mathrm{R} \$)$ & $43,632.65$ & $37,848.38$ & $-1,441.28$ & $133,459.47$ \\
\hline Net margin $1^{*}(\mathrm{R} \$)$ & $17,472.50$ & $26,692.61$ & $-20,620.25$ & $74,777.79$ \\
\hline Result (profit or loss) $1 *(\mathrm{R} \$)$ & $-6,987.12$ & $19,515.56$ & $-50,454.88$ & $49,514.50$ \\
\hline Gross margin $1 * / \mathrm{kg}$ milk $(\mathrm{R} \$ / \mathrm{kg})$ & 0.54 & 0.22 & -0.07 & 2.73 \\
\hline Net margin $1 * / \mathrm{kg}$ milk $(\mathrm{R} \$ / \mathrm{kg})$ & 0.12 & 0.34 & -1.03 & 1.85 \\
\hline Result (profit or loss) $1 * / \mathrm{kg}$ milk & -0.25 & 0.49 & -1.95 & 1.10 \\
\hline Profit $1(\%)$ & -0.21 & 0.36 & -1.34 & 0.37 \\
\hline Yield $1(\%)$ & -0.01 & 0.05 & -0.09 & 0.17 \\
\hline Profit $2(\%)$ & 0.07 & 0.25 & -0.71 & 0.61 \\
\hline Yield $2(\%)$ & 0.03 & 0.05 & -0.04 & 0.21 \\
\hline Total quantity of milk produced & $94,309.44$ & $98,480.98$ & $15,572.00$ & $466,859.00$ \\
\hline Quantity of milk sold & $93,701.37$ & $98,412.50$ & $14,850.00$ & $465,669.00$ \\
\hline Quantity of milk, internal consumption & 608.07 & 579.57 & 0.00 & $2,390.00$ \\
\hline Quantity of milk produced/day & 258.38 & 269.81 & 42.66 & $1,279.07$ \\
\hline Quantity of milk sold/day & 256.72 & 269.62 & 40.68 & $1,275.81$ \\
\hline Mean price of milk & 0.99 & 0.16 & 0.81 & 1.64 \\
\hline Total operating cost $/ \mathrm{kg}$ milk & 1.23 & 0.46 & 0.66 & 2.48 \\
\hline Effective operating cost $/ \mathrm{kg}$ milk & 0.80 & 0.33 & 0.27 & 1.69 \\
\hline Total cost $/ \mathrm{kg}$ of milk & 1.60 & 0.61 & 0.94 & 3.41 \\
\hline Fixed cost $/ \mathrm{kg}$ of milk & 0.60 & 0.28 & 0.19 & 1.46 \\
\hline
\end{tabular}


continuation

Variable cost $/ \mathrm{kg}$ of milk

Asset variation in animals (final valueinitial value)
1.00

$17,533.70$
0.41

0.56

1.95

* Considering only 20 production systems

$\mathrm{SD}=$ standard deviation.

The total operating cost (TOC) (Table 3) was obtained by adding the net operating cost (NOC) (expenditure) to the asset depreciation costs and family labour remuneration. The average NOC was $\mathrm{R} \$ 73,793.90$ and represented the producer's expenditures in funding his or her activities. The items comprised in the NOC were divided into groups (Table 4) because, per Lopes and Lopes
(1999), this allows monitoring milk production system costs, thereby helping technicians and producers obtain more detailed analyses. The feed group's average proportion (64.36\%) was above the $55.16 \%, 57.33 \%, 60.95 \%$ and $45.83 \%$ obtained by Lopes et al. (2006c, 2008b, 2007a) and Reis et al. (2001), respectively, but below the $76.20 \%$ obtained in Lopes et al. (2006b) studies.

Table 4. Descriptive statistics of the percentage (\%) of each net operating cost (NOC) item for 28 dairy farms in the Triangulo Mineiro and Alto Paranaiba (MG) region for January-December 2013.

\begin{tabular}{lcccc}
\hline \multicolumn{1}{c}{ Item } & Mean & SD & Minimum & Maximum \\
\hline Feed & 64.36 & 16.42 & 14.64 & 93.67 \\
Labour & 7.00 & 12.08 & 0.00 & 56.80 \\
Taxes (IPVA and ITR) & 0.18 & 0.63 & 0.00 & 3.26 \\
Health & 6.12 & 3.42 & 1.74 & 15.47 \\
Milking & 1.05 & 1.25 & 0.00 & 4.89 \\
Reproduction & 1.03 & 1.40 & 0.00 & 4.38 \\
Energy & 5.48 & 3.46 & 0.00 & 22.60 \\
Land rental (pasture) & 2.50 & 4.33 & 0.00 & 18.58 \\
Miscellaneous costs & 12.29 & 7.67 & 0.00 & 36.72 \\
\hline
\end{tabular}

$\mathrm{SD}=$ standard deviation.

The labour group had a minimum value of zero (Table 4), as most properties (81.48\%) did not hire a workforce, which was also found by Lopes et al. (2006a). The average proportion in this study was $7.00 \%$, compared with $11.56 \%$ in Lopes et al. (2010) and $15.51 \%$ in Reis et al. (2001).

Animal health care costs (Table 4) are related to the use of curative (antibiotics and antitoxins) and preventative (vaccines, antibiotics used in dry cow treatments, and antiparasitics) medicines and health tests. The average value $(6.12 \%)$ was higher than those obtained by Moura et al. (2010) - 3.00\%, Ferrazza et al. (2015a) - 5.80\%, and Reis et al. (2001) - 3.81\%. The higher percentage found in this study was due to management failures at two properties, resulting in increased medicinal costs to treat mastitis, leading to a maximum percentage of health spending (15.47\%). Studies on the economic impact of mastitis have shown a clear need to prevent this disease because prevention is much 
cheaper than curative treatment (DEMEU et al., 2011; LOPES et al., 2011b, 2012; DEMEU et al., 2015, 2016).

The high percentage spent on health care indicates that technicians and farmers must determine whether health problems exist in the herd and look for alternatives to remedy them quickly, as diseases compromise the animal's productivity, increase medical expenditures and can result in losing the animals. The literature does not specify an ideal health care value, and advocating a value of zero for this item would be unreasonable because a percentage must be invested in prevention, as per Demeu et al. (2015), prevention is more economical than curative medicines.

The average proportion of the milking group $(1.05 \%)$ (solutions acquired pre- and post-dipping, acid and alkaline detergents, paper towels, disinfectants and other products used in milking) (Table 4) was near the $1.03 \%$ found by Lopes et al. (2006b). Lopes et al. (2011a) noted the need to adopt preventative measures as well as management measures, especially during milking, and hygienic conditions at the installations to reduce new mastitis infections. Lopes et al. (2004b) found that a significant portion of dairy farmers failed to exercise care in hygienically obtaining milk, as when they surveyed all net operating expenses for 16 dairy farms in southern Minas Gerais, they found that 50\% spent nothing on acquiring pre- and post-dipping solutions, acidic and alkaline detergents, paper towels, disinfectants or other products intended for milking. These authors warned that, unfortunately, most producers neglect such practices.

Most properties 18 (66.67\%) had milking machines, which was well above the $15.00 \%$ reported in FAERJ's (2010) study, possibly due to the technical assistance that 17 properties $(62.96 \%)$ received. Such assistance helps producers decide to invest in milking equipment, which improves hygiene and quality standards, resulting in increased values paid per litre of milk, hence increasing the property's profitability. Unfortunately, despite the guidance and commitment from all technicians, many producers do not act on this advice, leading to undesirable production results.

In the reproduction group (Table 4; semen, liquid nitrogen, and insemination materials), the minimum value of zero occurred because 12 producers (44.44\%) did not adopt artificial insemination, thereby contributing to the decreased average. The average percentage $(1.03 \%)$ was higher than the $0.20 \%$ in Lopes et al. (2007a) study, the $0.13 \%$ in Lopes et al. (2010) and the $0.14 \%$ in Lopes et al. (2015).

In the energy group (fuel and electric power), the average value $(5.48 \%)$ was within the range of $4.40 \%$ to $5.63 \%$ observed by Carvalho et al. (2009) and similar to the $5.42 \%$ observed by Lopes et al. (2015), the $2.45 \%$ by Lopes et al. (2010) and the $5.00 \%$ at some properties in Moura et al. (2010) study but was below the $10.78 \%$ from Lopes et al. (2004b). The minimum value came from a property that lacked a milking machine and had minimal facility structure; the maximum was observed at a property with a poorly technified production system, in which the electricity expenses could not be separated from those of the residence and fuel used in the family vehicle. This attitude demonstrates that producers and rural entrepreneurs often cannot separate the activity's costs and investments from those incurred in their personal and family lives. This leads to negative results and causes many producers to give up their dairy business, not because it was unprofitable but because the production activity was unmanaged.

The land rental group representation was low at $2.50 \%$ of the NOC (Table 4). However, $40.74 \%$ (11 farmers) used rented pastures. The zero minimum value refers to 16 properties $(59.26 \%)$ that did not rent pastures, and the highest, $8.40 \%$, refers to a property in which the entire production area was rented. This proportion has two implications: one positive, wherein the property used all its resources 
and was growing and thus needed more pasture for the herd; the other, negative, wherein no productive planning occurred, and the animals lacked food, hence the need to rent the pasture.

The proportion of the various expenses group (12.29\%; machine and installation maintenance, office supplies, cleaning products, and taxes) was under the $16.27 \%$ in Lopes et al. (2007b) and the $14.45 \%$ in Lopes et al. (2010).

Fixed taxes, such as ITR (real estate property tax) and IPVA (automotive vehicle tax) had low average values because 21 producers $(77.78 \%)$ reported no expenditures on this type of tax. IPVA-related values were lacking because many producers lack vehicles. Regarding ITR, one producer lacked land and rented the one he used, and the other producers were small and thus exempt from this tax (MINISTÉRIO DA FAZENDA, 2013).

In rural enterprises, knowing each NOC component's proportion relative to the revenue is of utmost importance. According to Lopes et al. (2011a), because properties exist that do not adopt cost control due to the required minimum 12-month data collection period, the relationships between items that compose the NOC with total revenue is an alternative that can be used to simplify the data collection, i.e., how much of the revenue the farmer spends per month on feed, labour, health, etc. Knowing the proportion of each NOC item gives us an idea of the activity's situation at any time point. This indicator should be estimated, particularly for properties with economic viability, to serve as a reference for farmers who still do not estimate their production costs. Table 4 presents the values estimated in this study.

In addition to NOC, depreciation (Table 6) forms part of the TOC. According Lopes et al. (2008a), although not an expenditure, the amount relating to depreciation represents a cash reserve that should be maintained to replenish capital assets (facilities, equipment, etc.) at the end of their useful life. Depreciation represented, on average, $19.96 \%$ of total operating costs, above the $4.00 \%$ and $13.67 \%$ reported by Lopes et al. (2010) and Lopes et al. (2007a), respectively.

Another component of TOC is family labour (Table 3). The maximum value of $29.63 \%$ refers to producers who adopted exclusively family labour. This averaged $7.02 \%$ of the TOC (Table 5), which is below the $26.81 \%$ reported in Lopes et al. (2007a) study of family-operated properties.

Table 5. Descriptive statistics of the percentage (\%) of each total cost item for 28 dairy farms in the Triangulo Mineiro and Alto Paranaiba (MG) region for January-December 2013.

\begin{tabular}{lcccc}
\hline \multicolumn{1}{c}{ Item } & Mean & SD & Minimum & Maximum \\
\hline Fixed costs (FC) & 32.82 & 24.76 & 23.17 & 87.97 \\
Land payments & 8.26 & 7.75 & 0.00 & 22.58 \\
Invested capital payments & 10.51 & 7.26 & 9.67 & 26.32 \\
Owner payments & 0.00 & 0.00 & 0.00 & 0.00 \\
Taxes & 0.06 & 0.16 & 0.00 & 0.65 \\
Depreciation & 14.00 & 11.16 & 5.79 & 38.42 \\
Variable costs (VC) & 67.18 & 78.99 & 26.87 & 340.72 \\
Effective operating costs & 59.31 & 77.59 & 8.91 & 329.32 \\
Feed & 37.12 & 46.69 & 2.93 & 192.51 \\
Family labour & 7.02 & 1.88 & 17.79 & 12.37 \\
& & & & continue
\end{tabular}


continuation

\begin{tabular}{lcccc} 
Occasional and contracted labour & 3.98 & 5.41 & 0.00 & 4.28 \\
Health & 3.47 & 6.10 & 0.70 & 28.19 \\
Milking & 0.69 & 1.18 & 0.00 & 4.15 \\
Reproduction & 0.70 & 1.21 & 0.00 & 3.46 \\
Energy & 3.05 & 3.68 & 0.00 & 11.59 \\
Land rental (pasture) & 1.70 & 3.07 & 0.00 & 8.40 \\
Miscellaneous costs & 8.80 & 15.83 & 0.00 & 65.40 \\
Working capital payments & 0.89 & 1.22 & 0.17 & 5.22 \\
\hline
\end{tabular}

$\mathrm{SD}=$ standard deviation.

TC represented the sum of fixed costs (FC) (sum of expenditures on land, invested capital, entrepreneurship, taxes considered fixed, and depreciation) and variable costs (VC) (sum of net operating costs, working capital and family labour expenditures) (Table 3). According Lopes et al. (2006b), fixed costs do not represent expenditures (except for taxes) but represent what must be invested in the activity for it to remain competitive compared with other economic activities. Lopes et al. (2008a) showed that if fixed costs are not contemplated, the farmer may lose equity and go into debt in the long run.

The proportion of fixed costs in terms of total cost (Table 5) was $32.82 \%$, which is higher than the $24.10 \%, 27.2 \%, 37.1 \%, 23.6 \%$ and $27.20 \%$ obtained by Lopes et al. (2011a), Almeida Júnior et al. (2002), Ferrazza et al. (2015a,b) and Lopes et al. (2008b), respectively. These results show that investment is proportional to much higher milk productions than the average found (LOPES et al., 2011a). Ideally, the lowest possible value should be obtained, as the absence of this cost does not compromise production and productivity and reflects an increased milk volume produced, thus reducing depreciation, which is an important component of fixed costs.

Lopes et al. (2011a) emphasised that regardless of the amount of milk produced, without purchases, sales of goods or higher taxes, fixed costs remain constant. Both production and productivity must be increased so that they are less representative in the $\mathrm{TC}$, and economies of scale must be achieved. Increased production efficiency, optimizing use of goods for production, and scaled production are alternatives. According Lopes et al. (2006b) and Ferrazza et al. (2015b), these practices can reduce the TOC per kg of milk.

The entrepreneur remuneration value was nil because no farmers had other paid activities. Variable costs (Table 3) comprise the same items that constitute net operating costs plus expenditures on working capital and family labour. Expenditures on working capital (savings rate of $6.19 \%$ yearly, approximately half the value of the dairy farming NOC) is questionable when applied to the milk producer, as most farmers have trade credit until their milk is sold, thus reducing the need for such capital. Its inclusion increases variable costs and reflects negatively on profitability and yield and results in unrealistically analysing the results (LOPES et al., 2016). The average representation of variable costs $(67.18 \%)$ in the TC (Table 5) was near the $70.02 \%$ found by Lopes et al. (2007a).

An average of $\mathrm{R} \$ 17,472.50$ was observed for net margin (Table 3). This shows that the revenue covered all expenses to be paid, the reserve relating to depreciation to be considered and family labour to be paid. Milk production in this case offered short and medium-term sustainability. 
When analysing the economic efficiency indicator result (gross revenue less total cost) (Table 3 ), the 28 properties' average value was negative, demonstrating that the activity failed to pay for all capital. This result implies that if actions are not taken to find and correct bottlenecks, the farmers will decapitalize.

The negative average of Profitability $1(-0.21 \%$; Table 3) means that for every R $\$ 100.00$ in revenue R\$ 0.21 was lost. Analysis of Profitability 2 reveals a gain of R\$ 0.07 for every $\$ 100.00$ in revenue. These values were higher because this indicator does not consider expenditures on land, invested capital, entrepreneurship, or expenditures on working capital (LOPES et al., 2011a).

Yield 1 was $6.18 \%$, which was lower than that of the savings book (6.19\%). Analysis of Yield 2 revealed a value of $6.16 \%$, which was also below the savings book value. An important factor contributing to the low profitability and yield scores was idle infrastructure, evidenced by the high depreciation percentage (Table 5).

To more realistically analyse the results, whether the herd's equity variation was positive must be verified, calculating the difference in reals $(\mathrm{R} \$)$, between the herd's asset value at the end and at the beginning of the study period. This change, when positive, may indicate that the herd is growing, that the herd has not yet stabilized or that the price of the animals has appreciated (LOPES et al., 2015). In this study, the herd's average equity value variation was positive (Table 3 ).

A negative result of $\mathrm{R} \$ 6987.12$ (Table 3) was found in terms of the properties' average, with an average equity value variation of $\mathrm{R} \$ 17,533.70$. The accumulated equity value in animals alone was considered as R\$ 10,576.84 (-R\$ $6956.86+\mathrm{R} \$$ 17,533.70). These values can be easily monetised because cattle have high liquidity.

Table 6 shows some technical/management indices. Production ranged from 42.44 to $1,278.79$ litres of milk/day, with an average of 259.07 $( \pm 269.18)$ litres of milk/day, and a milk productivity per ha/year of 3,248.03 litres, which is considered small compared with the values found by Gomes (1999), Schiffler et al. (1999) and Lopes et al. (2011a). This index, combined with the number of cows per ha (0.71), shows that the areas have unutilized capacities. Average daily milk production was $256.07 \mathrm{~kg}$, with a productivity of $11.56 \mathrm{~kg}$ per lactating cow. This is low, and whether only correcting and adjusting the property management is necessary or whether a greater investment in cow genetics is needed should be ascertained. Demeu et al. (2016) stated that optimizing materials such as vaccines and materials for pre- and post-dipping affect the property's profitability because they do not change as a function of productivity.

Table 6. Technical/management indices for 28 family-operated dairy farms in the Triangulo Mineiro and Alto Paranaiba (MG) region for January-December 2013.

\begin{tabular}{lcccc}
\hline \multicolumn{1}{c}{ Specification } & Mean & Standard deviation & Minimum & Maximum \\
\hline Depreciation/TOC (\%) & 19.91 & 379.56 & 8.68 & 36.27 \\
EOC/TOC (\%) & 64.95 & $1,237.18$ & 23.70 & 88.09 \\
Family labour/TOC (\%) & 15.14 & 288.74 & 1.65 & 47.31 \\
Fixed costs/total cost (\%) & 36.97 & 704.54 & 17.19 & 59.45 \\
Variable costs/total cost (\%) & 63.03 & $1,200.83$ & 40.55 & 82.81 \\
Depreciation/total cost (\%) & 15.12 & 288.15 & 6.84 & 23.46 \\
Animal productivity/day (kg of milk) & 11.56 & 18.56 & 6.06 & 9.67
\end{tabular}


continuation

\begin{tabular}{lcccc} 
Daily production (kg of milk) & 259.07 & 269.18 & 42.44 & $1,278.79$ \\
Total production cost per hectare/year $(\mathrm{kg})$ & $3,248.03$ & $2,352.35$ & 626.50 & $8,628.53$ \\
Number of lactating cows/ha (cows) & 0.71 & 0.68 & 0.70 & 0.85 \\
Total production cost/labour (kg/service) & 218.59 & 683.01 & 42.44 & 639.40 \\
Cow/man ratio & 18.54 & 9.79 & 7.00 & 43.00 \\
Breakeven point (kg of milk/day)* & 157.46 & 535.18 & 157.46 & $2,039.70$ \\
\hline
\end{tabular}

*Considering only 20 production systems.

$\mathrm{SD}=$ standard deviation

In seven production systems (25.93\%), the average variable cost was higher than the milk's selling price; thus, ascertaining the breakeven point was impossible. The average breakeven point of 20 production systems was $157.46 \mathrm{~kg}$ milk/day, of which, the average daily production was $321.17 \mathrm{~kg}$. These values are above those reported by Lopes et al. (2004a), who also found that in $37.5 \%$ of properties, estimating the breakeven point was impossible with a daily average production of $268.96 \mathrm{~kg}$. According Lopes et al. (2004), these results indicate that more managerial and likely technological effort must be invested to increase the daily average without increasing the average variable cost, which, once increased, will further increase the breakeven point. Alternatively, these authors indicated increasing production efficiency, e.g., productivity per cow, optimal labour costs, medicine, artificial insemination, fixed taxes, energy and others. By increasing productivity per head, such expenses should not be increased.

The descriptive statistics of the percentage (\%) of each net operating cost/milk revenue (NOC/ $\mathrm{MR}$ ) item for 28 family-operated dairy farms in the Triangulo Mineiro and Alto Paranaiba (MG) region for January-December 2013 is the apresentadas and the table 7.

Table 7. Descriptive statistics of the percentage (\%) of each net operating cost/milk revenue (NOC/MR) item for 28 family-operated dairy farms in the Triangulo Mineiro and Alto Paranaiba (MG) region for January-December 2013.

\begin{tabular}{lcccc}
\hline \multicolumn{1}{c}{ Item } & Mean & SD & Minimum & Maximum \\
\hline Contribution of each item to EOC/milk income & 78.26 & 76.80 & - & 78.42 \\
Feed & 62.59 & 60.10 & 32.82 & 58.34 \\
Labour & 6.71 & 6.96 & 0.00 & 5.56 \\
& & & & \\
Health & 5.85 & 7.86 & 7.85 & 8.54 \\
Milking & 1.16 & 1.52 & - & 1.26 \\
Reproduction & 1.18 & 1.55 & - & 1.05 \\
Energy & 5.15 & 4.73 & - & 3.51 \\
Maintenance of machinery, installations & - & - & - & - \\
Land rental (pasture) & 2.87 & 3.95 & - & 2.54 \\
Miscellaneous costs & 14.84 & 20.37 & - & 19.82 \\
\hline
\end{tabular}

$\mathrm{SD}=$ standard deviation 


\section{Conclusions}

Socioeconomic factors (place of residence, producer's age and educational level, and land tenure) did not affect the gross margin, net margin, Yield 1, Profitability 1, Yield 2 or Profitability 2.

Considering the average values obtained from the studied properties, their positive gross and net margins showed that dairy farming was productive in the short and medium terms; however, financial capitalisation was less than the expenditures obtained with the savings book.

The component items of the net operating costs that comprised most of the costs of dairy farming in descending order were feed, sanitation, and energy, while those for total cost in descending order were feed, depreciation, and return on invested capital.

The component items of the net operating costs that occupied most of the dairy business revenues in descending order were feed, labour, and miscellaneous expenses.

\section{References}

ALMEIDA JÚNIOR, G. A.; LOPES, M. A.; PINATTO, F. Efeito da venda de animais na rentabilidade de um sistema intensivo de produção de leite tipo B no estado de São Paulo. In: REUNIÃO ANUAL DA SOCIEDADE BRASILEIRA DE ZOOTECNIA, 39., 2002, Recife. Anais... Recife: SBZ, 2002. p. 1-4. CD-ROM.

ASSIS, L. P.; VILLELA, S. D. J.; LOPES, M. A.; SANTOS, R. A.; RESENDE, E. S.; SILVESTRE, L. H. A.; SILVA, H. B. F.; MARTINS, P. G. M. A. Análise econômica e de custos de produção da atividade leiteira durante 10 anos em uma propriedade do Alto Vale do Jequitinhonha.Custose@gronegócio On line, Recife, v. 13, n. 2, p. 176-200, 2017.

BARROS, H. Economia agrária. Lisboa: Livraria Sá da Costa, 1948. 348 p.

BRUHN, F. R. P.; LOPES, MARCOS A.; MORAES, FLÁVIO de; PERES, A. A. C. Technical and economic indices that determine the profitability of milk production systems participating in the Full Bucket program. Semina: Ciências Agrárias, v. 38, n. 4, p. 1905-1916, 2017. DOI: 10.5433/1679-0359.2017v38n4p1905
CARVALHO, F. M.; RAMOS, E. O.; LOPES, M. A. Análise comparativa dos custos de produção de duas propriedades leiteiras, no município de Unaí-MG, no período de 2003 e 2004. Ciência e Agrotecnologia, Lavras, v. 33, p. 1705-1711, 2009. Edição Especial.

COSTA, J. H. C.; HÖTZEL, M. J.; LONGO, C.; BALCÃO, L. F. A survey of management practices that influence production and welfare of dairy on family farms in southern Brazil, Journal of Dairy Science, Elsevier, v. 96, n. 1, p. 307-317, 2013. DOI: 10.3168/jds.2012-5906

DEMEU, F. A.; LOPES, M. A.; COSTA, G. M.; ROCHA, C. M. B. M.; SANTOS, G. Efeito da produtividade diária de leite no impacto econômico da mastite em rebanhos bovinos. Boletim de Indústria Animal, Nova Odessa, v. 73, n. 1, p. 53-61, 2016.

DEMEU, F. A.; LOPES, M. A.; COSTA, G. M.; ROCHA, C. M. B. M.; SANTOS, G.; FRANCO NETO, A. Influência do descarte involuntário de matrizes no impacto econômico da mastite em rebanhos leiteiros. Ciência e Agrotecnologia, Lavras, v. 35, n. 1, p. 195-202, 2011.

DEMEU, F. A.; LOPES, M. A.; ROCHA, C. M. B. M. da; COSTA, G. M. da; SANTOS, G. dos; FRANCO NETO, A. Influência da escala de produção no impacto econômico da mastite em rebanhos bovinos leiteiros. Revista Ceres, Viçosa, v. 62, n. 2, p. 167-174, 2015. DOI: 10.1590/0034-737X201562020006

FEDERAÇÃO DA AGRICULTURA, PECUÁRIA E PESCA DO ESTADO DO RIO DE JANEIRO - FAERJ. Diagnóstico da cadeia produtiva do leite do Estado do Rio de Janeiro. Rio de Janeiro: FAERJ: SEBRAE-RJ, 2010. $181 \mathrm{p}$.

FERRAZZA, R. A.; LOPES, M. A.; BRUHN, F. R. P.; FLAVIO, M. Índices de desempenho zootécnicos e econômico de sistemas de produção de leite com diferentes tipos de mão de obra. Ciência Animal Brasileira, Goiânia, v. 16, n. 2, p. 193-204, 2015a. DOI: 10.5433/1679-0359.2015v36n1p485

FERRAZZA, R. A.; LOPES, M. A.; MORAES, F.; BRUHN, F. R. P. Índices de desempenho zootécnico e econômico de sistemas de produção de leite com diferentes níveis tecnológicos. Semina: Ciências Agrárias, Londrina, v. 36, n. 1, p. 485-496, 2015b. DOI: 10.5433/1679-0359.2015v36n1p485

GOMES, A. P.; ALVES, E. Identificando ineficiências na produção de leite. Boletim do Leite, Piracicaba, v. 6, p. $1-2,1999$.

IBM SPSS Statistics for Windows, Version 20.0. Armonk: IBM Corporation, 2011. 
INSTITUTO BRASILEIRO DE GEOGRAFIA E ESTATÍSTICA - IBGE. Censo agropecuário 2006: Agricultura Familiar; Primeiros Resultados; Brasil, Grandes Regiões e Unidades da Federação. Rio de Janeiro: IBGE, 2006b. Disponível em: <http://biblioteca. ibge.gov.br/visualizacao/periodicos/50/agro_2006 agricultura_familiar.pdf $>$. Acesso em: 02 ago. 2017.

INSTITUTO BRASILEIRO DE GEOGRAFIA E ESTATÍSTICA - IBGE. Censo agropecuário 2006: Brasil, Grandes Regiões e Unidades da Federação. Rio de Janeiro: IBGE, 2006c. Disponível em: <https:// biblioteca.ibge.gov.br/visualizacao/periodicos/51/ agro_2006.pdf $>$. Acesso em: 29 dez. 2017.

INSTITUTO BRASILEIRO DE GEOGRAFIA E ESTATÍSTICA - IBGE. Pesquisa Pecuária Municipal (PPM). Rio de Janeiro: IBGE, 2006a. Disponível em: $<$ http://biblioteca.ibge.gov.br/visualizacao/periodicos/ 50/agro_2006_agricultura_familiar.pdf $>$. Acesso em: 02 ago. 2017.

LOPES, M. A.; CARDOSO, M. G.; CARVALHO, F. M.; LIMA, A. L. R.; DIAS, A. S.; CARMO, E. A. Efeito do tipo de sistema de criação nos resultados econômicos de sistemas de produção de leite na região de Lavras (MG) nos anos de 2004 e 2005. Ciência Animal Brasileira, Goiânia, v. 8, n. 3, p. 359-371, 2007a. DOI: 10.1590/ S1413-70542004000500028

LOPES, M. A.; CARMO, E. A.; LIMA, A. L. R.; CARVALHO, F. M. Análise de rentabilidade de uma empresa com opção de comercialização de queijo ou leite. Arquivo Brasileiro de Medicina Veterinária e Zootecnia, Belo Horizonte, v. 58, n. 4, p. 642-647, 2006b. DOI: 10.1590/S0102-09352006000400028

LOPES, M. A.; CARVALHO, F. de M. Custo de produção do leite. Lavras: Ed. UFLA, 2000. 42 p. (Boletim Agropecuário, 32).

LOPES, M. A.; DEMEU, F. A.; COSTA, G. M.; ROCHA, C. M. B. M.; ABREU, L. R.; SANTOS, G.; FRANCO NETO, A. Influência da contagem de células somáticas sobre o impacto econômico da mastite em rebanhos bovinos leiteiros. Arquivos do Instituto Biológico, São Paulo, v. 78, n. 4, p. 493-499, 2011 b.

LOPES, M. A.; DEMEU, F. A.; ROCHA, C. M. B. M.; COSTA, G. M.; FRANCO NETO, A. SANTOS, G. Avaliação do impacto econômico da mastite em rebanhos bovinos leiteiros. Arquivos do Instituto Biológico, São Paulo, v. 79, n. 4, p. 477-483, 2012.

LOPES, M. A.; DIAS, A. S.; CARVALHO, F. M.; LIMA, A. L. R.; CARDOSO, M. G.; CARMO, E. A. Efeito da escala de produção nos resultados econômicos de sistemas de produção de leite na região de Lavras (MG,
Brasil), em 2004 e 2005. Asociación Latinoamericana de Producción Animal, Maracay, v. 16, n. 3, p. 121-129, $2008 \mathrm{a}$.

LOPES, M. A.; DIAS, A. S.; CARVALHO, F. M.; LIMA, A. L. R.; CARDOSO, M. G.; CARMO, E. A. Efeito do tipo de mão-de-obra nos resultados econômicos de sistemas de produção de leite na região de Lavras (MG) nos anos de 2004 e 2005. Revista Brasileira de Agrociência, Pelotas, v. 16, n. 1-4, p. 125-132, 2010.

LOPES, M. A.; CARDOSO, M. G.; CARVALHO, F. M.; DIAS, A. S.; LIMA, A. L. R.; CARMO, E. A. Resultados econômicos da atividade leiteira na região de Lavras (MG) nos anos 2004 e 2005: um estudo multicasos. Arquivo Brasileiro de Medicina Veterinária e Zootecnia, v. 60, p. $428-435,2008$ b.

LOPES, M. A.; DIAS, A. S.; LIMA, F. M. L.; RIBEIRO, A. L.; CARDOSO, M. G.; CARMO, E. A. Resultados econômicos de sistemas de produção de leite com diferentes níveis tecnológicos na região de Lavras-MG nos anos 2004 e 2005. Ciência e Agrotecnologia, Lavras, v. 33, n. 1, p. 252-260, jan./fev. 2009.

LOPES, M. A.; LIMA, A. L. R.; CARVALHO, F. M.; REIS, R. P.; SANTOS, I. C.; SARAIVA, F. H. Controle gerencial e estudo da rentabilidade de sistemas de produção de leite na região de Lavras (MG). Ciência e Agrotecnologia, Lavras, v. 28, n. 4, p. 883-892, 2004b.

LOPES, M. A.; LIMA, A. L. R.; CARVALHO, F. M.; REIS, R. P.; SANTOS, I. C.; SARAIVA, F. H. Efeito da escala de produção nos resultados econômicos de sistemas de produção de leite na região de Lavras (MG): um estudo multicasos. Boletim de Indústria Animal, Nova Odessa, v. 63, n. 3, p. 177-188, 2006 a.

LOPES, M. A.; LIMA, A. L. R.; CARVALHO, F. M.; REIS, R. P.; SANTOS, I. C.; SARAIVA, F. H. Efeito do tipo de mão-de-obra nos resultados econômicos de sistema de produção de leite na região de Lavras (MG): um estudo multicascos. Revista Ceres, Viçosa, MG, v. 54 , n. 312 , p. $172-181,2007$ b. DOI: $10.18539 /$ CAST. V16I1-4.2020

LOPES, M. A.; LIMA, A. L. R.; CARVALHO, F. M.; REIS, R. P.; SANTOS, I. C.; SARAIVA, F. H. Efeito do tipo de sistema de criação nos resultados econômicos de sistemas de produção de leite na região de Lavras (MG). Ciência e Agrotecnologia, Lavras, v. 28, n. 5, p. 11771189, 2004a. DOI: 10.1590/S1413-70542004000500028

LOPES, M. A.; LOPES, D. C. F. Desenvolvimento de um sistema computacional para cálculo do custo de produção do leite. Revista Brasileira de Agroinformática, Campinas, v. 2, n. 1, p. 1-12, 1999. 
LOPES, M. A.; MORAES, F.; CARVALHO, F. M.; PERES, A. C. C.; BRUHN, F. R. P.; REIS, E. M. B. The effect of technological levels on profits of milk production systems participating in the full bucket program: a multicase study. Semina: Ciências Agrarias, Londrina, v. 36, n. 4, p. 2909 -2922, 2015. DOI: 10.5433/1679-0359.2015v36n4p2909

LOPES, M. A.; SANTOS, G.; RESENDE, M. C.; CARVALHO, F. M.; CARDOSO, M. G. Estudo da rentabilidade de sistemas de produção de leite no município de Nazareno, MG. Ciência Animal Brasileira, Goiânia, v. 12, n. 1, p. 58-69, 2011 a.

LOPES, M.A.; CONTINI, E.; BRUHN, F. R. P.; CUNHA, E. A. S.; FARIA, P. B.; ROCHA, C. M. B. M. Fatores associados à percepção e atitude de consumidores de carne bovina com certificação de origem em Campinas. Veterinária e Zootecnia, v. 23, n. 2, p. 285-296, 2016. DOI: $10.4322 /$ rbcv.2014.037

MAROCO, J. Análise estatística com utilização do SPSS. Lisboa: Sílabo, 2007. 824 p.

MATSUNAGA, M.; BEMELMANS, P. F.; TOLEDO, P. E. N.; DULLEY, R. D.; OKAWA, H.; PEDROSO, I. A. Metodologia de custo de produção utilizada pelo IEA. Agricultura em São Paulo, São Paulo, v. 23, n. 1, p. 123139, 1976.

MINISTÉRIO DA FAZENDA. Imposto sobre a propriedade territorial rural (ITR): perguntas e respostas. Secretaria da Receita Federal do Brasil. Brasília, 2013. Disponível em: <http://www.receita.fazenda.gov.br/ publico/itr/2013/PerguntaseRespostasITR2013.pdf>. Acesso em: 18 jul. 2014.

MORAES, F.; LOPES, M. A.; BRUHN, F. R. P.; CARVALHO, F. M.; LIMA, A. L. R.; REIS, E. M. B. Efeito de índices técnicos e gerenciais na rentabilidade da atividade leiteira com diferentes tipos de mão de obra. Archivos Latinoamericanos de Producción Animal, Maracay, v. 24, n. 1, p. 29-38, 2016.

MOURA, J. F. P.; PIMENTA FILHO, E. C.; GONZAGA NETO, S.; LEITE, S. V. F.; GUILHERMINO, M. M.; MENEZES, M. P. C. Análise econômica da exploração de leite no cariri paraibano. Acta Scientiarum. Animal Sciences, Maringá, v. 32, n. 2, p. 225-231, 2010. DOI: 10.4025/actascianimsci.v32i2.7115
REIS, R. P.; MEDEIROS, A. L.; MONTEIRO, L. A. Custos de produção da atividade leiteira na região sul de Minas Gerais. Organizações Rurais e Agroindustriais, Lavras, v. 3, n. 2, p. 45-54, 2001.

SCHIFFLER, E. A.; MÂNCIO, A. B.; GOMES, S. T.; QUEIROZ, A. C. Efeito da escala de produção nos resultados econômicos da produção de leite $\mathrm{B}$ no estado de São Paulo. Revista Brasileira de Zootecnia, Viçosa, MG, v. 28, n. 2, p. 425-431, 1999.

SERVIÇO BRASILEIRO DE APOIO ÀS MICROS E PEQUENAS EMPRESAS - SEBRAE. Curso de capacitação rural. Goiânia: Ed. Sebrae/GO, 1998. 34 p.

SERVIÇO BRASILEIRO DE APOIO ÀS MICROS E PEQUENAS EMPRESAS - SEBRAE. Diagnóstico da pecuária leiteira do Estado de Minas Gerais em 2005: relatório de pesquisa. Belo Horizonte: FAEMG, 2006. $156 \mathrm{p}$.

SILVA, M. F.; SILVA, A. C. Análise dos indicadores zootécnicos e econômicos do sistema de produção de leite a pasto com suplementação. Revista Brasileira de Agropecuária Sustentável (RBAS), Viçosa, MG, v. 3, n. 1, p. 110-116, 2013.

SOLANO, C.; LEÓN, H.; PÉREZ, E.; TOLE, L.; FAWCETT, R. H.; HERRERO, M. Using farmer decisionmaking profiles and managerial capacity as predictors of farm management and performance in Costa Rican dairy farms. Agricultural Systems, Örebro, v. 88, n. 2-3, p. 395428, 2006. DOI: $10.1016 /$ j.agsy.2005.07.003

STÜLP, V. J. A evolução regional da produtividade da mão-de-obra no setor agropecuário do Rio Grande do Sul. Ensaios FEE, Porto Alegre, v. 27, n. 2, p. 377-410, 2006.

TEIXEIRA JÚNIOR, F. E. P; LOPES, M. A.; RUAS, J. R. M.; SILVA, M. A. O. Efeito dos manejos de amansamento de primíparas no préparto e do maior peso vivo ao parto na rentabilidade da atividade leiteira. Revista Brasileira de Ciência Veterinária, Niterói, v. 23, n. 12, p. 81-86, jan./jun. 2016. DOI: 10.4322/rbcv.2016.035

TEIXEIRA JÚNIOR, F. E. P.; LOPES, M. A.; RUAS, J. R. M. Efeito da idade de aquisição de fêmeas de reposição na rentabilidade da atividade leiteira. Boletim da Indústria Animal, Nova Odessa, v. 72, n. 1, p. 59-68, 2015 . 
